\title{
Democracy and Trade Unions in Vietnam
}

\author{
Riding a Honda in Low Gear
}

\section{IRENE NØRLUND}

\section{Introduction}

The economic reforms started in the early 1980s in Vietnam. A crucial question is why the transformation of industrial relations was able to take place without a major reaction from the working class who were experiencing fundamental changes in its working and living conditions.

One of the reasons is that the institutions in Vietnamese society have played a distinct role in formulating their own interests during the transformation period. The trade unions are one of the important institutions in labour relations in the state-owned and foreignfunded sector. They have increasingly assumed the role of a twoway "transmission belt"1 between the management and the labour force. The question now is whether the unions are increasingly becoming a workers' organization or merely a tool of the state in order to carry out a smoother transformation of the society? Are the trade unions contributing to an increasingly substantive democracy $?^{2}$

These questions contain implicit theoretical considerations about the character of the "state", of the "party" and of "society". They are related to the debate both of societies in a neo-socialist transformation, ${ }^{3}$ and of the NIC countries (and maybe newly emerging NICs) in East and Southeast Asia, which have embarked on a quick industrialization process with quite impressive results. The purpose of this essay is to look at some theoretical approaches that serve to establish a framework for a broader understanding of the role of the trade unions in Vietnam in the period of economic transformation, and also to consider some specific characteristics in the Vietnamese development.

As there has so far been no detailed theoretical and empirical investigation into the trade unions in Vietnam and their societal context, I have chosen another country, namely China, since 
it parallels Vietnam in a number of ways. ${ }^{4}$ This will be followed by a survey of the theoretical and empirical approaches to analyses of the transformation in Vietnam in order to obtain a context for the role of trade unions there.

\section{Corporatism, Civil Society and Trade Unions: Chan and White on China}

The trade unions in China have recently come under scrutiny in works by Anita Chan and Gordon White. ${ }^{5}$ The insurrection at Tiananmen in 1989 brought the social movements into focus again. Chan takes as her point of departure the situation in the late 1980s and investigates whether the institutional agitation from above by ACFTU (All China Federations of Trade Unions), and independent spontaneous protest from below were two elements which could join together, or whether they merely exhibited tendencies to move in the same direction. ${ }^{6}$ Her opinion about the neo-socialist societies is that the one-party states are not totally monistic, and that bureaucratic organizations sometimes seek to establish their own separate identity. ${ }^{7}$ The theoretical framework for her empirical analysis takes as its starting point Schmitter's definition of the corporate state:

Corporatism can be defined as a system of interest representation in which the constituent units are organized into a limited number of singular, compulsory, noncompetitive, hierarchically ordered and functionally differentiated categories, recognised or licensed (if not created) by the state and granted a deliberate representational monopoly within their respective categories in exchange for observing certain controls on their selection of leaders and articulation of demands and supports. ${ }^{8}$

The definition is supplemented by a reference to Daniel Chirot, who argues that,

Communist one-party systems are one variant of corporatist states. The communist state creates vertical functional institutions and places them under central control, with the expressed purpose of pre-empting any horizontal coalescing of class interests. ${ }^{9}$

The role of trade unions in the classical socialist state is characterized by "classical dualism" (Pravda and Ruble, 1986), where the trade unions ideally provide a dual function as a two-way transmission belt 
between the workers and the party centre. ${ }^{10}$ The enterprise managers and workers are assumed to have coinciding interests. However, as Chan argues, the classical dualism is inherently contradictory, because in reality the transmission is usually a one-way, top-down transmission of the party directives. ${ }^{11}$ In her analysis Chan shows that ACFTU, in spite of its subordinated relation to the party, came to have more influence than might have been predicted. The changing role of the trade unions is seen, on the one hand, in the light of the economic reforms which brought about rapid income polarization among the different social sectors and within the enterprises and, on the other hand, of deteriorating labour-management relations due to rationalization of production processes of a Taylorist style, ${ }^{12}$ which she considers both undemocratic and exploitative.

Chan argues that economic reforms and liberalization bring about new social groups, the beginning of political liberalization, and the gradual establishment of horizontal autonomous groupings. This process is what some scholars of China have described as the emergence of civil society. However, Chan prefers to stay out of this debate and calls it an "emergent civil society ... as a sort of game in which neither state nor society is yet the winner". ${ }^{13}$ She finds the concept of state corporatism versus societal corporatism more appropriate, where the latter would imply a sectorally structured model which represents grassroots interests, unlike state corporatism or independent labour groups which confront the state directly. ${ }^{14}$ Conservative factions in the party realized that it was necessary to reform ACFTU if a movement "à la Solidarity" was not to emerge in China. Consequently, a number of reforms took place, including a shift to an election of trade union representatives rather than appointment by the party. Moreover, legislation about labour relations was promulgated to secure the right of the trade unions in a number of respects in the Trade Union Law (1993) and Labour Code (1994).

In the tense situation leading up to the Tiananmen upheaval, ACFTU leaned towards the side of the protest movement, while at the same time seeking to function as a mediator between the society and the state. The trade unions came out stronger of the conflict and won greater influence in daily decisions at enterprise level. Chan interprets their increasing influence as an expansion of their corporatist power, at the expense of some of the more radical elements who wanted autonomous trade unions. ${ }^{15}$ The policy of the latter went too far for the 
authorities and in the wake of the upheaval the autonomous trade unions were crushed. ACFTU was allowed to continue and consolidate its bureaucratic power. However, Chan concludes that this will only be critical for the regime when ACFTU is recognized and accepted by its constituency and reaches down to the grassroots, which is not yet the case in spite of the present changes. One possibility is that workers will take militant action and will feel that exploiting the existing bureaucratic structure is the most effective means to further their own class interests. She considers, nevertheless, this type of evolution of the corporatist structure as "perhaps the least risky and tortuous route visible on the horizon toward worker representation". ${ }^{16}$

Gordon White deals with the same topic in two recent publications. ${ }^{17}$ The role of the trade unions is adopted as the central focus, as in Chan's article, but the theoretical framework is different. White does not perceive Chinese society as corporatist, neither at the outset of reform nor at present. The aim of the book is to explore the utility of the concept "civil society" in describing and understanding the social and institutional consequences of the historically novel form of market transition in the Chinese context. ${ }^{18}$ White is sceptical about the concept, but none the less discusses it in the context of neo-socialist transformation. Civil society is considered a sociological definition, "an intermediate associational realm situated between the state on one side and the basic building blocks of society on the other (individuals, families and firms)", and not a political definition which would imply a political society "based on a particular set of institutionalized relationships between state and society based on the principles of citizenship, civil rights, representation, and the rule of law". ${ }^{19}$ In this way he avoids the discussion of political parties which otherwise is a problem in one-party states.

White sees post-1978 Chinese society in the context of state-society relations framed by the interplay between a dual set of dynamics: (a) the political dynamics, which he calls the "totalistic" political institutions, has an impact on tensions and conflicts which are emerging in the process and (b) the market dynamics. The civil society is perceived as an outcome of the process of separation of state and society due to the rise of a market economy and related social strata, with the implication that social power is distributed away from the state. The market economy contains the potential for creating new institutions and shifting the balance of power between state and society. ${ }^{20}$ This 
shift of power will presumably undermine the authoritarian political order and facilitate a transition towards political liberalization and ultimately some form of democratic polity. ${ }^{21}$

White et al. investigate two types of organizations for this purpose. The first type consists of mass organizations which existed before the reforms: the trade union federation and the women's organizations, both of which belong to the "incorporated" sector. The latter represents new organizations which grew up because of the reforms and intertwined state and society. This group of new organizations counts among its members entrepreneurs, industrialists, enterprise managers and self-employed people. The analysis aims at contributing to an understanding whether the organizations represent a civil society or have developed as more fully-fledged corporate institutions.

The conclusion of the large empirical investigation identifies an emerging civil society, "albeit embryonic, uneven, and with conflicting interests". The methodology of identifying "civil society" is however somewhat limited, because it gives a static picture and even turns the focus too exclusively on the formal associations, whereas the relationship between the formal and informal sphere of associations is just as crucial. At the same time, the focus on civil society also diverts the attention from changes in the structure and behaviour of the state. ${ }^{22}$ A special period in China was the early years of reform from 1978, when a relaxed political climate allowed both former organizations (like ACFTU) and business associations to develop along with new organizations. By the mid-1980s the political and market forces started to reinforce each other and created a fairly liberal atmosphere. This "liberal" development ran into conflict in the wake of the Tiananmen insurrection in 1989, when conservative forces achieved more power and enforced a stronger policy of repression and inclusion. When in 1992 the economic reforms were reimplemented, the state attempted to control existing mass organizations; it undermined their social credibility and drove genuine popular associations underground through the repressive apparatus. ${ }^{23}$

Some background information is needed here to place the trade unions in a historical context. Before 1966, the trade unions had several crises and confrontations with the party: in 1951, 1957 and 1960. By 1966 they were actually dismantled as an institution and played virtually no role in labour relations. They were only allowed 
to reemerge when the reform period was introduced in $1978 .^{24}$ Private enterprises and self-employment increased very rapidly and ushered in a new type of labour relations where the party and trade unions played little part. However, labour relations in the state and collective industrial sector (where lifetime employment was the norm), remained largely unaffected up to the early 1990s, according to White et al..$^{25}$ However, enterprise management and labour relations changed fundamentally in the 1990s. The manager was granted more power, and legislation was introduced to regulate the role of the trade unions. The legislation gave the unions a raison d'être and a certain power; and the workers were transformed from the "ideological masters" of the socialist system to "commodities" in an increasingly competitive labour market. The trade unions were caught "in a social nutcracker" between the membership on one hand, which had become increasingly diversified and demanding, and management on the other, which had become more powerful in the wake of the newly introduced Taylorist management methods. ${ }^{26}$ In order to defend the interests of the workers in the state enterprises, the unions had to play a conservative role, but as representatives of the new workers in the non-state sector their role had to be more innovative.

By the mid-1990s, however, the power balance between the state and the social organizations seemed to have changed, because the state was pushing the burden of financial support on the organizations themselves and in that way increasing the power potential of the social groups. Whereas the authors do not provide a label for the character of relations before the mid-1990s; they say that "to the extent that corporatist controls are maintained, this would imply a transition from state corporatism to societal corporatism", which, however, would undermine the very basis of incorporation itself and possibly lead to proliferation of competing organizations. ${ }^{27}$ To see the potential for a peaceful political transition (including democratization) in China in a comparative perspective, the authors point to a possible combination of developments in the Soviet Union and South Korea. In the Soviet Union the transition to democratic rule was organized by reformist elements within the existing political elite, whereas in South Korea the old elite had to relinquish power to opposition politicians and forces from the new business elite, supported by organizations like the trade unions and church groups. ${ }^{28}$ An alternative scenario 
would be the increasing "political struggle between state and society leading to some form of takeover or collapse of the state". ${ }^{29}$

\section{Corporatist or Not?}

One of the assumptions made by both Chan and White et al. is that the trade unions in principle would want greater autonomy from the party and government. Before the events at Tiananmen, the chairman of ACFTU envisaged the establishment of a corporatist arrangement in the unions, ${ }^{30}$ but after the events there seemed to be a trade-off between ACFTU and the party. Because of the trade unions' loyalty to the party, it was decided to give higher priority to urban workers, to increase the influence of the trade unions in the policy-making process and at the enterprise level. ${ }^{31}$ For the more radical economic reformers, the trade unions were an obstacle to fundamental reforms of the industrial state sector. The alliance between conservative reformers and the unions aimed at giving the unions more legitimacy among their constituency by securing the welfare policy of the state and collective enterprises. At the same time ACFTU became more like a "pillar of the government" than an independent organization. ${ }^{32}$ White et ai. agree with Chan about the historical facts and results for the trade unions, but they envisage less opportunity for democratic changes through the trade unions. The reality was that the trade unions were separated neither from the party nor from the state, but their influence increased, and this might even have made the ACFTU leaders want to refuse to separate from the party.

Chan concludes that the state corporatist construction is changing, but it is not clear exactly in which direction it is moving, although she would predict a new social upheaval or collapse of the state if state corporatism is not democratized. She sees some chance of an evolution of the state corporatist structures into a more societal corporatist structure, if ACFTU tries hard enough to reach its constituency. ${ }^{33}$ White and his co-authors finished their writings several years later than Chan, but they are doubtful if the system developing in China could be called corporatist at all before 1995. ACFTU is not considered part of "civil society". The trade unions achieved at local level, micro or sectoral, some kind of corporatist structures, ${ }^{34}$ but at the national level ACFTU is becoming increasingly bifurcated, adopting a different role in the state enterprises and the private sector. The corporatist 
perspective is possible, in the viewpoint of White et al., provided (my emphasis) a tripartite system is introduced in which the unions are guaranteed a monopoly in labour representation. ${ }^{35}$ And this option is regarded as urgent if the unions are not to be compromised vis-à-vis their constituencies and be vulnerable to attack from independent labour organizations. Even if political conditions are favourable for a corporatist solution, its feasibility remains in doubt. ${ }^{36}$

Another interesting development started in China in the mid-1990s. An increasing number of independent labour organizations, especially in the coastal zones where there is major foreign investment, have rapidly emerged, working as underground secret organizations. Also in Beijing and other large cities, independent organizations have appeared, in these cases mainly in the state enterprises where workers are dissatisfied with the large lay-offs and bankruptcies. The other tendency is that there are factions within the trade unions that speak for free trade unions and accuse ACFTU of not being able to protect the interests of the workers. ${ }^{37}$ The "real" civil society in this sense, according to White et al., is to be found in these unofficial, underground organizations. ${ }^{38}$ Chan wrote her article before this tendency emerged so clearly.

The two points of view (Chan and White) reveal the difficulty of applying the concept of corporatism. In spite of their agreement about the factual events, the two groups of authors disagree on the fundamental character of the structures in China. Chan accepts the possibility of negotiation between the corporatist parties, even if the catchword for state corporatist structures is top-down control. Their context is important, as they mainly look at corporatist structures in East Asia, where the states have a common cultural bias favouring corporatism. Moreover, Chan includes the role of Confucianist teachings, which stress "common good through leadership authority and paternalistic morality". ${ }^{39}$ White, on the other hand, has the global corporatist discussion in mind when he analyses Chinese society, and finds it difficult to draw parallels between China and, for instance, corporatist systems in Western Europe. It appears as if White looks more to the future prospects for transformation than Chan, and views democratization as inevitable. Chan sees a possibility for ACFTU to play its role better as a (democratic) workers' organization, whereas White can hardly see how corporatism can be feasible, because of inherent contradictions. He leaves open the possibility of challenge 
from the underground workers' organizations as representatives of autonomy and political freedom. Whether that will lead to a collapse of the state is not explicitly expressed.

The details of the two analyses do not differ fundamentally; even the conclusions lead in the same direction. They both predict that democratization will take place one way or another along with market reforms. Other authors on China would argue that there is not much democratization taking place, because new types of control are being developed. ${ }^{40}$ The question is whether other approaches might consider some of the changes taking place in societies like China and Vietnam without clearly signalling the establishment of democracy or the reverse.

\section{State, Party and Civil Society in Vietnam}

How does the role of the state and civil society in Vietnam compare to the situation in China? What was the reason for the quiet transformation around 1990, when the labour force was reorganized and some 200,000 to 300,000 employees in the industrial state sector lost their jobs? Is there any connection between the lack of civil society and the relatively peaceful transformation? Or is the quiet transformation due to increased participation by workers and trade unions? How can these changes be explained from an analytical point of view?

If White's definition of a civil society (excluding enterprises) is applied, there is barely a civil society in Vietnam, as genuine autonomous associations are a new phenomenon, ${ }^{41}$ and still extremely weak at the political level. ${ }^{42}$ Most of the definitions of "civil society" cannot accommodate the type of transformation taking place in Vietnam at this stage, or in China for that matter, and it is of little use if we consider the trade unions. ${ }^{43}$ The concept has not been subject to such close scrutiny and discussion in relation to Vietnam as it has to China. However, those researchers who have involved themselves in the debate are fairly much in agreement that, if civil society is to have any relevance for Vietnam, it must be capable of emerging from within the adapted institutions of the society: cooperatives, state organizations, mass organizations, factories and so forth. ${ }^{44}$

There are, of course, differing opinions on how these changes have taken place, on the basic character of the society and the direction in which it is moving. Ben Kerkvliet points to four approaches to state- 
society relations. The first approach views society as a totalitarian body with a strong party-state that excludes alternative and autonomous societal organizations from the national centre down to the grassroots of the village and the workplace. It has been labelled "mono-organizational socialism" 45 or a model of "bureaucratic polity". The second approach perceives the state and the communist party as a corporatist organization where social institutions are used to further the state's and party's own interests. The third interpretation allows a much more definitive role for the societal forces, with a "penetrating civil society" in order to explain the differences between the official state policy and the actual situation. It does not, however, see a possibility for the society to influence the state. Finally, the fourth approach makes room for social pressures and demands on the state, also from two of the basic classes of support for the party: the workers and the peasants. ${ }^{46}$ This latter view would include "everyday political" approaches and what in the Vietnamese context is called "fence breaking", i.e. cases when societal (including economic) forces have taken their own initiatives and institutionalized various changes that have had to be approved a posteriori by the party and the state. The idea of "fence breaking" came up in Vietnamese literature in 1979 and later came to have considerable influence on the Western thinking about Vietnam's economic and social changes as initiated from the bottom and not the top. ${ }^{47}$

In the "fence breaking" approach there exist no definite limits between the state and civil society, and the conflicts in society might as well take place within the given institutions as outside. If this approach is accepted, it is easier to understand how the changes of the official thinking were possible, also as an internal process, because of constant pressures from below. From the dogmatic socialist thinking of the mid-1970s when the goal was socialist construction with emphasis on heavy industry, the party dogma has, according to Fforde and Porter, shifted to accept the inability of Marxism-Leninism to predict exactly where and how the society will develop as the market economy progresses. ${ }^{48}$.

What can be learned from other countries in Asia? Undoubtedly, the impressive economic development in the NIC countries has had an impact on the Vietnamese party-state in the search for a new and more efficient development policy in the 1980s. It was more than a challenge to see the "economic miracles" of the NIC countries while 
the economy was in deep crisis in 1979-81, and probably the main external reason that steps were taken to change the dogmatic economic policy. Change came along with the economic reforms, and especially when foreign investment in Vietnam was encouraged from 1987 and development aid and loans increased in the 1990s. A situation emerged (as in China) whereby the society had to cope with these new phenomena which needed a much more diversified structure than had existed previously. The institutional setup was faced with a changing environment.

\section{Economic Periodisation and Impact on Society}

Adam Fforde and Stefan de Vylder present a "bottom-up" (the fourth) approach to the political economy for the period 1979-95. ${ }^{49}$ The economic transformation is analysed not as part of the reform policy of the party-state, but as a bottom-up process, which makes the changes possible step by step. The first period of reform (1979-85) is called a hybrid transformation or a period of hard reform socialism, not changing the basic principles of the classical socialism (here called neo-Stalinism or the DRV (Democratic Republic of Vietnam) model, which is the version of neo-Stalinism applied in Vietnam). There followed a period of soft reform socialism (1986-89), which is the period when doi moi (reformation) was introduced. ${ }^{50}$ By 1990, Vietnam could be characterised as basically a market economy after a number economic reforms had been put in place:

- the two-price system had been abolished;

- the currency had been made convertible;

- the economy had been opened up for foreign investments and trade;

- the "state subsidies system" had changed into a "cost-accounting system" based on market prices and not central planning.

The authors conclude that the Vietnamese economy from 1989-90 can best be analysed as a market economy and no longer as a transitional one, ${ }^{51}$ and 1990-94 is considered a period of macro-economic stabilization which forms the base for "the final stages of the shift from systemic change to accelerated development"..$^{2}$ From this period the authors consider Vietnam more like other developing countries in the region. ${ }^{53}$ The analysis is based on historical methods in spite of their economist training. This is probably a choice based on the difficulty or 
inability, so far, for the social sciences to develop theoretical tools to grasp the transformations of neo-socialist societies.

The state is perceived as a weak state, especially in the period 198589 , when it sought to accommodate pressures from various interest groups. "The state became increasingly confused in its objectives as line ministries and local authorities became more and more involved, through the state, in business activities." ${ }^{154}$ This confusion and indecisiveness are perceived as one of the reasons for the imposition of the "rule by law" which was speeded up in the early 1990s and the state was strengthened. ${ }^{55}$ The book by Fforde and de Vylder gives a broad view of the transformation, mainly from a macro-perspective, in all its contradictions and coincidences with the international development. It is an acceptable approach to understand how the ruling classes around the party-state were able to abandon their dogmatic adherence to a classical socialist development model in favour of a flexible approach that accepts policies of "trial and error". So far, the development has not really threatened the ruling classes, and in general there has been broad public support for the reforms because the necessary economic improvements have been considerable in the overall view. The book is both challenging and innovative, even though, of course, it can still form a basis for debate. The analysis provides a number of key concepts to facilitate an understanding of more specific areas, like business enterprises and the trade unions, and the overall ideological change that took place.

The weakness of the book is that it does not help much in a systematic, theoretical understanding of the transformation. It is difficult to relate to a comparative study with other countries. It does, for instance, not explain why the ideology that became dominant from about 1989 in Vietnam is so similar to the one appearing in China under Deng around the same time. ${ }^{56}$ If the process is spontaneous from the bottom up without certain dominating forces, it is hard to believe that the same ideas and structures in so many respects would develop in China. Even if the present author in many areas agrees with the historical framework set up by Fforde and de Vylder, some contradictions appear in the analysis of the economic situation at the enterprise level in the period after 1990, which still is limited by the institutional setting and is not fully a market economy. I would argue that the institutional changes were not as far-reaching as the economic changes: this furnishes another perspective on the society which falls 
within the parameters of the economic analysis. Fforde and de Vylder admit, though, that they have less to say about political changes because they fall outside the scope of the book.

In an ideal approach for analysis, the Vietnamese transformation should be related to both the Chinese and the East and Southeast Asian transformations. Various foci and levels have to be taken into consideration to analyse the development trends in relation to the trade unions: the state (party-state); the economy/state enterprise; the unions/institutions; and the workers/individuals. At each level and field, the culture has to be taken into consideration. ${ }^{57}$ External political and cultural influences like the "waves" of ideas that impact upon every society to some extent (if it is not totally cut off from the world) combined with the local tradition and culture should also be included. ${ }^{58}$ Of course, it is essential to integrate history into the analysis, first because therein lie the roots of most later development, not least the cultural norms and attitudes, and second because, at a lower level of abstraction, the historical approach is able to contain the specific events and trends in the societal change that has contributed to the present state of affairs. It might also be the only way to point at the dynamics of the change, as the driving forces change over time and certain events have a specific international context.

\section{Corporatism in Vietnam?}

The question is whether the debates that have taken place in relation to the other countries can be partly applied to bring some "order" to the analysis of the Vietnamese transformation. The discussion of "civil society" seems only to bring a partial understanding of the space for the increased non-state activities in neo-socialist societies. This is especially the case if the enterprises are excluded from the discussion, and if there is no account taken of the changing role of the trade unions, which are part of the party and state..$^{59}$ Is "corporatism" a helpful analytical tool? Ideas of corporatism were first applied in Europe and Latin America, which were more pluralistic than East and Southeast Asia. Unger and Chan make an important point when they contend that corporatist arrangements do not define any political system; they are instead institutional mechanisms in the service of governments and particular sectoral constituencies. Unger and Chan point to corporatist arrangements in South Korea, Taiwan, Japan and 
China with widely differing political regimes. ${ }^{60}$ China had corporatist structures imported from the Soviet model. As for the trade unions, the situation became extreme when the ACFTU was abolished under Mao in the period 1966-78. In the 1980s the opportunity for various associations grew, and China approached state corporatism - but from the opposite direction to the East Asian NICs: not as a mechanism for further strengthening the state's hold over the economy and society, but rather as a mechanism through which the state's hold could be loosened. ${ }^{61}$ Corporatism must nevertheless be regarded as different in the various regions of the world.

White does not perceive China as having corporatist structures in the pre-reform period, although he sees some types of corporatism developing at local or community level today. These might lead to conflict more than agreement with higher levels or other communities: a fragmented and fragmenting corporatism which reflects the increasingly pluralistic nature of the Chinese state system as a whole. ${ }^{62}$ In the ACFTU, however, the introduction of a tripartite system is considered as a corporatist arrangement. ${ }^{63}$

In Vietnam, the model from the Soviet Union was also applied in the form of societal organization and structures, but the history differs from the Chinese. When the Cultural Revolution started in China in 1965, Vietnam (DRV) was involved in the bombardments from the US. Where China experienced conflicts and splits within the party, Vietnam experienced a much more harmonious albeit authoritarian period where there was little space for that type of conflict. Fforde and de Vylder suggest that the DRV model can be viewed as a bargaining economy rather than a command economy, and that the central control was much less strict in reality than it appeared on paper. ${ }^{64}$ The trade unions were important organizations for supporting the workers in the factories, often partly destroyed by the US bombardments. They helped workers when production was decentralized into the rural areas, and when the workers were evacuated into the provinces in order to evade the bombardments. There was never a direct confrontation between trade unions and the party, as there was in China. The trade union played a subordinated role: it implemented the decisions of the party, encouraged production and took care of the daily concerns of the workers. Vietnam came probably closer to a "state corporatist" system during the DRV period and up to around 1988-90 than China did. 
The corporatist structures can also be interpreted as a process of inclusion of the mass organizations, as Ken Jovitt asserts: he says that socialist states are undergoing a transformation dating back to the time of the revolution. The first period is consolidation of the new regime and harsh suppression of other factions. The second is a transformation which leads to a consolidation. In this period the party builds a new political system based on the predominant ideas of the party and new structures according to the ideology: an industrial base, military power and intelligentsia, thereby destroying the traditional institutions. The third phase is when the consolidation is obtained and the task of the party is to integrate rather than isolate itself from the society, which Jovitt calls "inclusion", i.e. of societal groups that emerged during the transformation and have now become incorporated into the regime. ${ }^{65} \mathrm{He}$ suggests furthermore an evolutionistic picture of the inclusive regime which changes from exercising power through command, dogmatic modes of action and organization towards emphasis on leadership, procedural and empirically oriented modes. Legislative and representative organs of the state are ideologically and institutionally upgraded ${ }^{66}$ Jovitt is mainly working on experiences from the USSR and Eastern Europe, but his evolutionary approach to the socialist systems, even before the reforms, is interesting, because a number of similarities can be found in China and Vietnam in the period of neo-socialism (i.e. after the reforms), even if it might be a less smooth process than he presents.

The revolution and establishment of the socialist regime by Jovitt's periodization can well be applied in Vietnam, but the inclusion period seems to have brought only limited changes of the evolutionary kind in China and Vietnam, and perhaps even in the USSR and Eastern Europe. Moreover, it is important to stress that the trade unions and other mass organizations were not included into the state but primarily connected to the party. The state was built on normative rules comprising traditions and Leninist ideas of organization, which basically was the party. The ideology in Vietnam claimed that the party was the leading and decisive organization; the "state" was the administration; and the mass organizations were another type of implementing body functioning through the enterprises and cooperatives. It was in many ways a very decentralized and somewhat "weak" administrative system penetrated at all levels by the party's ideological rules. 
Party-state is a much better expression than state, and the process that has taken place since the end of the 1980s can to a great extent be regarded as a process of separation of the party and the state. The rule of the party has been limited in the state, thereby leaving its institutions a certain degree of autonomy in deciding practical matters. This process is still ongoing, far from finished, and it will probably take quite some time to complete, even with the attempts at reversal (like the situation in 1996). State institutions, such as the national assembly, have gained in influence and power, not least in the project of establishing a regime of "rule by law". There may be several reasons for a legal system to be built up in the 1990s: conflicting interests in the party (as argued by Fforde and de Vylder); an evolutionary aspect of inclusion (according to Jovitt); and also the confrontation with the "outside" world, which forces the state to establish laws in order to encourage foreign investments and foreign aid. The society today is too complicated to be ruled by ideology, tradition and custom alone; and official approval has been given to the "rule by law" (not to be confused with the "rule of law"). This goes hand in hand with the project of separating the party and the state, and the separation of the various institutions from the party, but it is not quite clear how this is to take place.

It is reasonable to consider Vietnam as having had a (party-state) corporatist structure until 1990. In the 1990s, I would still consider the system as corporatist, but of a changing version where the institutions are now becoming increasingly equal partners, which might lead to a societal type of corporatism. The process is far from finished, and it is still not certain where it will lead. This is perhaps one of the important obstacles to the transformation of the neo-socialist states, because it is acknowledged that further reform is necessary. New power relations have to be established, and power is not voluntarily given away without compensation at least. In the process of defining the relationship between party and state, one tendency is that party cadres are increasingly taking up positions in economic life as enterprise directors or owners and are pushing for further reforms of enterprise structures. 


\section{Trade Unions, Enterprises and Workers in Vietnam}

Several good reasons can be suggested why the trade unions are an important focus of attention in the transformation of the neo-socialist societies. After the revolution of 1945 and the peace of 1954, the partystate was established with the Leninist institutions set up after the model of the USSR. The state was called a workers' and peasants' state, but in the Vietnamese revolution the workers have been the core force of the revolutionary movement since the late 1920s (unlike in China, where the peasants were more important in Mao's revolutionary thoughts). The state-owned enterprises, most of them taken over after the French retreat, were the organizational units of the working class, with the trade unions as the "transmission belt" between party and workers.

The Vietnam Federation of Trade Unions (VFTU) was established in 1946, and the first congress took place in Viet Bac, the northern liberated provinces, in $1950 .{ }^{67}$ In the Trade Union Law of 1957, the trade unions were supposed to take part in the economic management of the state and of enterprises, so they had their official position in the corporatist institution. The trade unions' goals were changing depending on the historical circumstances. During the Vietnam War (1964-75) the emphasis shifted to the ideological role; but after the reunification of 1976, the trade unions' role was "to mobilize, organize, educate and train the workers". It was also mentioned that they should "protect the legitimate interests of the workers and employees and take care of their living conditions". 68

The enterprises in the socialist countries had a double function of being economic and production units and at the same time social and political units. The trade unions were organized according to the Leninist principle of dualism. On the one hand, their job was to mobilise workers for production; this included maintaining discipline, and educating the workers about production, management and ideology. On the other hand, they had to defend labour interests and be the guardian of members' legal rights against management. ${ }^{69}$ In the Stalinist version, the last part of the dual function was reduced, because there could be no contradiction between labour and management in a socialist state. This "classic dualism" ${ }^{170}$ was introduced in all socialist countries. State enterprises were those organizations where the core "proletariat" of the revolution was situated and which were the new experimental creations of the revolution. It was here that the 
workers came into contact with the party and the officials. They were the origin of the new industrial capital accumulation which was to bring the country into the communist society of the next century. When the country decided to open up for foreign investments in December 1987, a new period was starting for the established state enterprises.

Nguyen Van Linh was elected president at the fourth congress of the VFTU in May 1978 for a period of five years. He became famous because of his stance on reform and his introduction of the doi moi programme at the sixth party congress in 1986, when he was elected the new secretary-general. The turning point for the VFTU was its sixth congress in 1988. It was held in a spirit of "renewal, openness and democracy". ${ }^{1}$ One of the core speeches was given by Nguyen Van Linh who pointed out the main challenges ahead of the trade unions:

- to review the content and methods of their activities and their organization and staff;

- to expand their work into the emerging private sector in a "multicomponent society";

- to change their name to Vietnam General Confederation of Labour (VGCL), according to the new content of the organization's work;

- to ensure their independent character in terms of organization;

- to voice ideas of their own, not opinions borrowed from the party committees or from management;

- to change the composition of the cadres so what they would not have to be party members as long as they were trained at the grassroots level or via trade union work. ${ }^{72}$

The speech was a revolution from above, with the blue stamp of the highest authority of the Communist Party, who knew well the situation of the trade unions. The pressures from the grassroots had not been able to change the organization as yet. The following year, 1989, saw a diminution of the openness in Vietnam: this was partly an effect of the insurrection at Tiananmen Square and the collapse of the Eastern European socialist regimes. However, trade union reforms started and were confirmed by the Trade Union Law of 1990, the State Constitution of 1992, the Constitution of the VGCL of 1993, and finally the Labour Code of 1994. The separation of management, party and trade unions is one of the important underlying themes. In the Trade Union Law of 1990, the trade unions still participated in the management of enterprises; however, 
in the state constitution and the later laws this changed, and the unions have been assigned a new role as "controllers and supervisors of state organs and economic units". Their main function is now to look after and safeguard the rights and interests of cadres, workers, employees and other labouring people. ${ }^{73}$

The intention of the legislation concerning the trade unions is clearly to separate the various institutions from one another both in organization and in formulation of goals in order to established a unified system between the various sectors in the "multi-component" economy. This is, however, a case where I would state that the legislation is somewhat ahead of reality. The trade unions are still more heavily involved in the management of the state-owned enterprises than in the privately owned and foreign-funded enterprises, where their influence tends to be restricted to areas like working conditions and social concerns. ${ }^{74}$ However, much of this influence goes through informal structures which are surviving the changes of the formal ones and which support a policy of consensus between the various partners: the management, the party and the trade unions. Open conflicts in the state-owned enterprises are reduced through the corporatist structure: solutions are usually found before it comes to open conflict and strike. Most of the major conflicts in Vietnam since 1989 have taken place in the foreign-funded enterprises. In China, White saw the trade unions caught in a social nutcracker as the membership became increasingly diversified between on the one hand the state sector workers' demand for security, and on the other hand the emerging proletariat in the non-state sector, who wanted a more innovative policy to defend themselves. The situation is somewhat similar in Vietnam, but I would analyse the situation differently: the trade unions have to expand their work into the non-state sector and learn how to operate within the new milieu. It is an important and urgent challenge which can be accomplished if the trade unions are no longer caught between party and management, and if they can formulate the interests of the workers. In spite of the necessity for further reforms, the VGCL seems to have contained the problems better in their reforms than the ACFTU was able to do. In that way the VGCL has avoided confrontation with independent unions unlike the situation in China, and has therefore maintained a reformed corporatist system with more legitimacy. ${ }^{75}$ 
Pravda and Ruble point to the fact that trade unions in the socialist countries are far from uniform, and that economic and social change make "classic dualism" less cost-effective for the regimes (an urgent task in emerging systems of market competition). They see signs of a move away from this type of dualism. They suggest various new types of unionism:

- corporatist dualism is usually sponsored from above by the unions and party officials aware of the need for more effective policy making;

- participatory dualism attracts the support of union officials, technicians, skilled workers and managers, and party officials who want to further economic reforms;

- adversarial non-dualism is usually a result of pressure from the grassroots to make more radical modifications of the proposals by party and union leaders.

In Vietnam elements of these various types seem to be at stake in the present period, depending on regional differences, sectors and enterprises. $^{76}$

\section{Preliminary Conclusions}

Why did the workers not react more strongly when reforms were enacted whereby 200,000 - 300,000 lost their jobs in the state-owned enterprises? The arguments in this context are that the trade unions managed to reform themselves sufficiently to contain some of the dissatisfaction and demands for reform; that the party clearly supported these reforms from the top; and that even the state, which became stronger after 1990, was able to support these reforms with legislation and social measures. This does not mean that it has been a smooth process, however: there has, for instance, been disagreement and debate at every step of the legislation promulgated. It could be argued that the lack of civil society, if this is to be identified with independent trade unions, is a reason for a fairly peaceful transformation. At the same time it is argued that it might not be the most relevant way to analyse the situation in Vietnam.

It was questioned whether the peaceful transformation was due to increased participation by trade unions and workers. There is no doubt that the trade unions assumed a more central role in the society, both because of the changing labour relations in the stateowned enterprises and because of the increasing number of joint- 
ventures and foreign-funded companies, where the trade unions are the only organization to secure the workers' conditions. If the trade unions are unable to establish themselves also in this sector, independent organizations may appear in Vietnam as they did in China.

The questions also need to be put whether the workers' participation is increasing or not and whether they are contributing to a more peaceful transformation? There is no final answer as yet to these questions. However, the changing structures of the trade unions allow the workers to take part more directly in the election of trade union leaders, and with the promulgation of the Labour Code in 1994, the workers have, for the first time, a written document whose rules and regulations have to be followed. In the foreign-funded, and to a certain extent in the state-owned enterprises, ${ }^{77}$ there is now a rule by law and it seems as if the workers have taken advantage of it. Gordon White pointed out that workers in China have been transformed from "ideological masters" to "commodities" in an increasingly competitive labour market. These trends can also be identified in Vietnam, but at the same time there are a number of obstacles to this process of change. The corporatist institutional relations in the enterprises prevent the development of a totally free labour market, or of a market mechanism for that matter.

Whether the trade unions are becoming workers' organizations or tools of the state cannot be answered simply. It can be argued that they are doing both to some extent. They are a tool of the state in their role of promoting a smoother transformation of society into the market-based mechanism. They also serve the workers' need to become organised and thereby protect their interests, which are being challenged under the new conditions. The conclusion so far is that the strength of labour depends on region, sector, branch and enterprise. The unions seem stronger in the south than in the north of the country; the state and foreign-funded sectors are much more regulated than the private and small-scale sectors; the individual industrial branches react differently to integration into both world and national competition; and the enterprise trade unions have very differing strengths. This is partly due to the national structure of the trade unions, which still have not lived up to the demands of a stronger vertical structure of the industrial branches, which can unify the working and income conditions. White stated earlier that the trade unions had to play a conservative role in the state 
enterprises and that reformers saw them as an obstacle to radical reforms. The same point of view can be found in Vietnam. However, there is a fairly broad political consensus about the necessity to give the workers the "best possible" living and working conditions in order to improve production and productivity, and at the same time to allow them to mobilize themselves against over-stringent treatment and exploitation by the upcoming capital which is finding itself less and less protected from international competiton. ${ }^{78}$ It is stipulated in the Labour Code that workers and trade unions can act to defend their interests, and workers have even without the Labour Code taken action to improve their conditions in a number of cases.

The type of corporatism that is developing in Vietnam today seems to allow more space for the administration and the trade unions in relation to the party. At the beginning of this essay it was stated that the trade unions were becoming a two-way transmission belt between management and labour. This is an important deviation from the former system where the trade unions were a transmission belt between the party and workers, and mainly a one-way, top-down transmission belt. At the same, time the cultural traditions of negotiating compromises and achieving consensus seem to play an important if not dominant role, which contributes to limit the market forces. The balance between the various institutions seems to be more successful than, for instance, in China. In Vietnam, the power of the party is declining, the power of state and administration is increasing, and the trade unions are beginning to fulfil their functions, namely to defend and protect the interests of the workers. ${ }^{79}$

It seems then that both institutions and individuals have gained a greater say in their own conditions in this period of economic reform and that dissatisfaction has been contained by the new structures for the time being. The substantive democratization of the society has come about. The question is whether corporatist compromise is healthy for economic development or political transformation? Moreover, is this balance more than a temporary transition from the neo-socialist regime to a market-based, pluralistic political system which might lead to painful political and social changes?

Irene Norlund (Ph.D. in history) is senior research fellow at the Nordic Institute of Asian Studies, Copenhagen, and a specialist in economic and social history of Vietnam. The article is a revised version of the paper 
"Democracy and Trade Unions in Vietnam: Riding a Honda at Slow Speed" presented at the American Association of Asian Studies, Chicago, 13-16 March 1997.

\section{NOTES}

1 In the socialist countries the trade unions were conceived as a "transmission belt" between party and masses: on the one hand, conveying party policy to labour and theoretically sending information from the shop-floor to the party hierarchy on the other hand. In this way they were closely subordinated to the party, but organizationally distinct from it (Alex Pravda and Blair A. Ruble eds., Trade Unions in Communist States (Boston, London, Sydney: Allen \& Unwin 1986), p. 4).

2 See Stein Tønnesson, "Please Be Precise when Researching Democracy", in NONESA, 1/95. Melanie Beresford and Irene Nørlund, "Democracy and Power in a Transitional One-Party State", in Ing-Britt Trankell and Laura Summers eds., Political Culture in Southeast Asia (Uppsala, forthcoming).

3 The term "neo-socialism" covers the processes of transformation in the socialist states which have started (fundamental) economic reforms but still not changed the political system from one-party states to more pluralistic political systems. Many concepts have been used about socialist states evolving from communist states, which is not a very appropriate term because these countries were never communist in the original sense of the word. State socialism is another variation (see for instance Clemens Stubbe Østergaard, "Economic Transformation in China. The Role of State vs. Market", in Laurids S. Lauridsen ed., Institutions and Industrial Development: Asian Experiences. Occasional Paper No. 16,
Roskilde University 1995). Ken Jowitt calls the socialist states Leninist regimes when he wants to indicate the specific organization ideology ( $\mathrm{K}$. Jovitt, New World Disorder. The Leninist Extinction (Berkeley: University of California Press, 1992)). In Vietnam the term neo-Stalinism has been used, for instance by Adam Fforde (A. Fforde and Suzanne $\mathrm{H}$. Paine, The Limits of National Liberation, (London, New York, Sydney: Croom Helm, 1987)). The problem about this terminology, like that of one-party state, is that it describes the political regime, but does not contain the economic transformation. The concept of market socialism is mainly used by the regimes themselves, and is often criticized for its inherent contradiction between mixing stateand market-driven societies (Gabriels Kolko, "Vietnam since 1975. Winning a War and Losing the Peace", Journal of Contemporary Asia, Vol. 25, No.1, 1995). Transitional society is probably a more appropriate term, but it does not indicate what kind of transition is taking place, or from what and to what. Post-socialist is used mainly about Russian and the other new states in Central Asia and in Eastern Europe, in which the political systems have changed after the breakdown of the socialist regimes.

4 Two studies have been carried out: Ulla Nielsen, Vietnamese Trade Unions at a Cross Road. The Implication of Structural Change for the Relationship between the State and Trade Unions in Vietnam (Copenhagen: The Copenhagen Business School, 1996); Eva 
Hansson, Trade Unions and Doi Moi. The Changing Role of The Unions in the Era of Economic Liberalization in Vietnam. A Minor Field Study (Stockholm: Department of Political Science, 1995).

5 One of the earlier articles about trade unions in China is Jeanne L. Wilson, "The People's Republic of China", in Pravda and Ruble eds., Trade Unions in Communist States (Boston, London, Sydney: Allen \& Unwin, 1986), pp. 219-51. Andrew Walder has moreover written an innovative work about labour relations in the stateowned enterprises before the reforms, Communist Neo-Traditionalism. Work and Authority in Chinese Industry (Berkeley, Los Angeles, London: University of California Press, 1986). However, he did not pay much attention to the trade unions in this work.

6 Anita Chan, "Revolution or Corporatism? Workers and Trade Unions in Post-Mao China", Australian Journal of Chinese Affairs, No. 29 (January 1993), p. 35.

7 Ibid., p. 34.

8 Philippe C. Schmitter, "Still a Century of Corporatism?", The Review of Politics, Vol. 36, No. 1, (January 1974), pp. 93-94.

9 Daniel Chirot, "The Corporatist Model and Socialism", Theory and Society, No. 9 (1980), pp. 367-69, quoted in Chan (1993), pp. 35-36.

10 Alex Pravda and Blair A. Ruble, "Communist Trade Unions: Varieties of Dualism", in Pravda and Ruble eds., Trade Unions in Communist States (Boston: Allen \& Unwin, 1986), p. 1 ff.

11 Chan, (1993), op, cit. p. 37.

12 Frederick Winslow Taylor (18561915) introduced the rationally organized industrial concept of "scientific management" with time studies and other measures to increase productivity. $\mathrm{He}$ was in general negative to unionization. His ideas have had an important impact in the twentieth century's industrial organization.

13 Chan (1993), op.cit., p. 45.

14 Schmitter (1974), calls it neocorporatism, according to Chan (1993), op.cit., p.45.

15 Ibid., p. 57.

16 Ibid., p. 61.

17 Gordon White, "Chinese Trade Unions in the Transition from Socialism: Towards Corporatism or Civil Society?", British Journal of Industrial Relations, Vol. 34, No. 3 (September 1996), pp. 433-57. Gordon White, Judy Howell and Shang Xiaoyuan, In Search of Civil Society. Market Reform and Social Change in Contemporary China (Oxford: Clarendon Press, 1996).

18 White et al., 1996, p. 2.

19 Ibid., pp. 3-4.

20 Ibid., pp. 7-8.

21 Ibid., pp. 9-10. A number of modifications and supplements are added in order not to make the hypothesis too rigid: The market hypothesis of the emergence of civil society is considered a hypothesis that has to stand for full or partial rejection or confirmation, based on the results of the investigation. It is also pointed out that a weak civil society does not necessarily equate with less democratization. There are other forces at stake in the process of democratization, like international influence and the domestic state-based elites (White et al., 1996, p.6).

22 Ibid., pp. 209-11.

23 Ibid., p. 211.

24 Ibid., p. 43.

25 Ibid., pp. 43, 65.

26 Ibid., pp. 43-45.

27 Ibid., p. 214.

28 Ibid., p. 217. 
29 Ibid., pp. 215-16.

30 Gordon White, "Chinese Trade Unions in the Transition from Socialism: Towards Corporatism or Civil Society?", British Journal of Industrial Relations, Vol. 34, No. 3 (September 1996), p. 443.

31 Gordon White, Jude Howell and Shang Xiaoyuan, In Search Of Civil Society (Oxford: Clarendon Press, 1996), p. 51.

32 Ibid., pp. 54-55.

33 Anita Chan, (1993), op. cit., pp. 59-61.

34 Gordon White, "Chinese Trade Unions in the Transition from Socialism: Towards Corporatism or Civil Society?", British Journal of Industrial Relations, Vol. 34, No. 3 (September 1996), p. 449.

35 Tripartism is the principle applied in labour relations of most market economies where the workers' and employers' organizations negotiate an agreement between the two partners and the state recognizes the result (ILO approved the convention on Tripartite Consultation in 1976, No. 144).

36 Gordon White, "Chinese Trade Unions in the Transition. ...", British Journal of Industrial Relations, Vol. 34, No. 3 (September 1996), p. 451.

37 White et al., In Search of Civil Society (Oxford: Clarendon Press, 1996), p. 63.

38 Ibid., p. 66.

39 See Unger and Chan, "China, Corporatism, and the East Asian Model", The Australian Journal of Chinese Affairs, No. 33 (January 1995), pp. 3134.

40 See Børge Bakken, Social Control and Policing in China, Occasional Paper (Copenhagen: NIAS), February 1997, p. 17.

41 Nguyen Ngoc Truong, Grassroots Organizations in Rural and Urban Vietnam during Market Reform: An overview of their emergence and relationship to the state. Paper to Vietnam Update 1994 Conference "Doi Moi, the State and Civil Society" (Canberra: ANU, 10-11 November 1994).

42 The position of civil society in Taiwan is a striking contrast to Vietnam, and shows that the conventional definition is applicable to other societies. See Michael Hsiao's article on "Social Movements and Civil Society in Taiwan" in this issue of Copenhagen Journal of Asian Studies.

43 Berrett L. McCormick argues that enterprises should be included in the definition of civil society in "Society and State in Vietnam and China: The Political Consequences of Economic Reform". Paper presented to the Vietnam-China Workshop at Contemporary China Center, the Australian National University (August 1995), p. 11.

44 See Adam Fforde and Doug Porter, "Public Goods, the State, Civil Society and Development Assistance in Vietnam: Opportunities and Prospects", Paper presented to the Vietnam Update 1994 Conference "Doi Moi, the State and Civil Society" (Canberra: ANU, 10-11 November 1994), p. 14. This conference is a major effort in the scholarly world concerned with Vietnam to discuss the concept and idea of civil society in Vietnam.

45 Carlyle Thayer is one of the spokesmen of this approach, but even he leaves some space for non-state activities and local power of the provinces, see for instance Carlyle A. Thayer, "Mono-Organizational Socialism and the State", in Benedict J. Tria Kerkvliet and Doug J. Porter, Vietnam's Rural Transformation (Boulder, Col.: Westview Press, 1995), pp. 39-64.

46 Ben Kerkvliet, "Rural Society and State Relations", in Benedict J. T. 
Kerkvliet and Doug J. Porter, Vietnam's Rural Transformation (Boulder, Col.: Westview Press, 1995), pp. 6667.

47 See Adam Fforde and Doug Porter (1994), pp. 11-21; David Marr, "The Vietnamese Communist Party and Civil Society", Vietnam Update (Canberra, 1994), p. 3.

48 Porter and Fforde, "Public Goods, the State, Civil Society and Development Assistance in Vietnam: Opportunities and Prospects", Vietnam Update (Canberra, 1994), p. 20.

49 Adam Fforde and Stefan de Vylder, From Plan to Market. The Economic Transition in Vietnam (Boulder, Col.: Westview Press, 1996).

50 Adam Fforde and Stefan de Vylder, From Plan to Market (Boulder, Col.: Westview Press, 1996), pp. 13-15, 13661.

51 Ibid., pp. 243-44.

52 Ibid., p. 298.

53 . Ibid., p. 20.

54 Ibid., p. 312, see also pp. 269-71.

55 Ibid., pp. 244, 268-69, 285.

56 See Torstein Hjellum, "On the Legitimacy of the Dengist Regime" in this issue of Copenhagen Journal of Asian Studies.

57 Ibid.

58 See the article by Geir Helgesen, "Cultural Undercurrents in the Waves of Korean Democratization" in this issue of Copenhagen Journal of Asian Studies.

59 This does not imply that it is not important to investigate and analyse what is happening in the civil society, on the contrary.

$60 \mathrm{~J}$. Unger and A. Chan, "China Corporatism, and the East Asian Model", in The Australian Journal of Chinese Affairs, No. 33 (1995), p. 37.

61 Ibid., p. 38.

62 White et al., In Search of Civil Society (Oxford: Clarendon Press,1996), p. 21.
63 Ibid., p. 64.

64 Fforde and de Vylder, From Plan to Market (Boulder, Col.: Westview Press, 1996), p. 258.

65 Ken Jovitt, New World Order, The Leninist Extinction (Berkeley, Los Angeles, Oxford: University of California Press, 1992), pp. 88-95. The chapter was first published in World Politics in 1975 and he has no knowledge of the societies in the 1980s and 1990s.

66 Ibid., pp. 96-97.

67 Le Movement Syndical au Vietnam (Hanoi: Éditions en langues étrangères, 1990), pp. 10-11.

68 Rules of the Vietnamese Trade Unions, in Fourth National Congress of the Vietnamese Trade Unions, Documents (Hanoi: Viet Nam Federation of Trade Unions, 1978), p. 213.

69 Alex Pravda and Blair A. Ruble, "Communist Trade Unions: Varieties of Dualism", in Pravda and Ruble eds., Trade Unions in Communist States (Boston, London, Sydney: Allen and Unwin, 1986) pp. 2-3.

70 Ibid.

71 The Sixth Congress of the Vietnamese Trade Unions, Vietnam Courier, No. 1, 1989 , p. 5.

72 Nguyen Van Linh, "The Trade Unions Must Renew their Activities", Vietnam Courier, No. 1, 1989, pp. 6-7.

.73 The Constitution of Vietnam 1992, Chapter 1, Article 10, in The Constitutions of Vietnam 1946-1959-1980-1992 (Hanoi: The Gioi Publishers, 1995), p. 158.

74 This is based on experiences from fieldwork and visits in 1994 and 1996 both to the north and the south of Vietnam.

75 See Anita Chan and Irene Nørlund, "Vietnamese and Chinese Labour Regimes. On the Road to Divergence", in Ben Kerkvliet and Anita Chan eds., Transforming Asian Socia- 
lisms. China and Vietnam Compared (preliminary title), forthcoming. This article points to a number of more detailed differences between China and Vietnam which are not discussed here for the lack of space.

76 Alex Pravda and Blair Ruble, "Communist Trade Unions: Varieties of Dualism", in Pravda and Ruble eds., Trade Unions in Communist States (Boston, London, Sydney: Allen \& Unwin, 1986), pp. 18-19.

77 As the labour market is developing in a segmented fashion, the small-scale sector will not follow the regulation as will the larger ones. See Irene Nørlund, "The Labour Market in Vietnam: Between State Incorporation and Autonomy", in Johannes Schmidt,
Jacques Hersh and Niels Fold eds., Southeast Asia's Social Change and Inequality (Addison Wesley Longman Limited) forthcoming.

78 Since the introduction of the market economy, the incomes and working conditions of the state workers differ substantially from sector to sector and from enterprise to enterprise. Based on visits all over the country, I am of the opinion that the total conditions for the workers are better in the state enterprises than in the private enterprises.

79 Admittedly, there was an attempt at a comeback by the party in 1996 , but political processes are never smooth. It does not change the general tendency of transformation. 